енергозберігаючих заходів на Framework for climate and energy policy регіональному рівні [Електронний ресурс]. [Електронний ресурс]. - Режим доступу : - Режим доступу : https://ec.europa.eu/energy/sites/ener/files/do http://old.niss.gov.ua/monitor/Monitor24/02. cuments/2014_eec_communication_adopted_ htm. 0.pdf.

17. Energy Efficiency and its contribution to energy security and the 2030

\title{
УДК 338.46:641
}

\section{ПРАКТИЧНІ АСПЕКТИ ВИКОРИСТАННЯ ХАРЧОВИХ ВІДХОДІВ НА ПІДПРИЕМСТВАХ ГОТЕЛЬНО-РЕСТОРАННОГО БІЗНЕСУ}

\author{
Бутенко О. П., к.е.н., доцент, \\ Стрельченко Д. О., магістр (ХНУБА)
}

У статті розглянута проблема забруднення навколишнього середовища харчовими відходами. Установлене завдання з необхідності мінімізації зазначених відходів та розроблена їх класифікації з визначенням напрямів одержання додаткового прибутку для підприємств, щзо їх утворюють. Запропоновані практичні кроки реалізації напрямів на прикладі конкретного підприємства, щзо дало змогу визначити рівень майбутніх витрат, зміни, які очікуються та рівень доходу. Установлено, щзо заохочення підприємств готельно-ресторанного бізнесу до ефективного управління гастрономічними відходами є перспективним напрямом не тільки для підприємиів, як можливість отримання додаткового прибутку, а й для країни у иілому через значне зменшення кількості токсичних відходів.

Ключові слова: забруднення навколишнього середовища, утилізація харчових відходів, утворення, складування та можливості вторинного використання харчових відходів для підприємств, сортування сміття, економічне обтрунтування заxодib.

\section{ПРАКТИЧЕСКИЕ АСПЕКТЫ ИСПОЛЬЗОВАНИЯ ПИЩЕВЫХ ОТХОДОВ НА ПРЕДПРИЯТИЯХ ОТЕЛЬНО-РЕСТОРАННОГО БИЗНЕСА}

\author{
Бутенко Е.П., к.э.н, доцент, \\ Стрельченко Д.А., магистр (ХНУСА)
}

В статье рассмотрена проблема загрязнения окружающей среды пищевыми отходами. Установлено задание по необходимости минимизации указанных отходов и разработана их классификация с определением направлений получения дополнительной прибыли для предприятий, которые их образуют. Предложены практические шаги реализации направлений на примере конкретного предприятия, что позволило определить уровень предстоящих расходов, изменения, которые ожидаются и уровень

(С) Бутенко О.П., Стрельченко Д.О.
Вісник економіки транспорту і промисловості № 61, 2018 
дохода. Установлено, что поощрение предприятий гостинично-ресторанного бизнеса $\kappa$ эффективному управлению гастрономическими отходами является перспективным направлением не только для предпринимателей, как возможность получения дополнительной прибыли, но и для страны в целом из-за значительного уменьшения количества токсичных отходов.

Ключевые слова: загрязнение окружающей среды, утилизация пищевых отходов, образование, складирование и возможности вторичного использования пищевых отходов для предприятий, сортировка мусора, экономическое обоснование мероприятий.

\title{
PRACTICAL ASPECTS OF USEING OF FOOD WASTES AT ENTERPRISES OF HOTEL AND RESTAURANT BUSINESS
}

\author{
Butenko O. P., candidate of Economic Sciences, associate professor, \\ Strelchenko D. O., master \\ (Kharkiv national university of architectures and buildings)
}

The article deals with the problem of environmental pollution with food waste. The task of minimizing these wastes was established and their classification was developed with the definition of directions of obtaining additional profit for the enterprises that make them. Practical steps of realization of directions on an example of the concrete enterprise were proposed, this allowed us to determine the level of future expenses, changes that are expected and the level of income. It is established that encouraging enterprises of the hotel and restaurant business to efficient management of gastronomic waste is a promising direction not only for entrepreneurs, as an opportunity to generate additional profits, but also for the country generally due to a significant decrease in the amount of toxic waste.

Keywords: pollution of the environment, utilization of food waste, formation, warehousing and the possibilities of re-use of food waste for businesses, sorting of garbage, economic reasoning of activities.

\section{Постановка}

Забруднення навколишнього середовища сьогодні є проблемою світового масштабу, рішення якої шукають i студенти, i громадські діячі, і науковці. Однією 3 головних причин цієї екологічної кризи $є$ проблема утилізація сміття. Трагедія 28 травня 2016 року на Грибовицькому звалищі під Львовом вкотре нагадала країні про невирішену екологічну проблему. На даний час, державні органи контролюють порушення правил збирання, зберігання, транспортування та використання промислових й інших відходів не належним чином, адже покарання за адміністративні та кримінальні порушення є незначними. До цього часу ще не було збудовано жодного спеціалізованого заводу 3 переробки токсичних промислових відходів, відсутня організована система збирання, зберігання та видалення токсичних відходів, відсутні техніка та обладнання для переробки відходів будівництва і комунального господарства. До токсичних відходів, що займають найбільшу частку від усіх інших, належать і харчові відходи, які становлять серйозну проблему для світової економіки і навколишнього середовища. За даними FAO (продовольча та сільськогосподарська організація об'єднаних націй), розвинені країни викидають до 40\% продуктів харчування. Серед країн Євросоюзу лідерами за кількістю харчових відходів $\epsilon$ Великобританія, Німеччина, Франція,

Вісник економіки транспорту і промисловості № 61, 2018 
Нідерланди і Польща. Так, Великобританія викидає 15 млн. тон продуктів у рік; Німеччина - 15 млн. тон; Франція - на €20 млрд у рік; Польща - 9 млн тон харчових відходів; США вартістю близько \$162 млрд на рік [1]. Викинутої їжі вистачило б, щоб нагодувати 870 мільйонів голодуючих. Третина всіх вироблених у світі продуктів не з'їдається, а загальна вартість викинутої у смітник їі досягає 400 мільярдів доларів на рік. Скорочення викидів метану $\epsilon$ пріоритетним завданням Агентства 3 охорони навколишнього середовища, яке бореться проти зміни клімату на планеті. Крім того, харчові відходи займають все більше i більше простору, створюючи потребу в збільшенні площі звалищ. Гниюча їжа також $є$ благотворним середовищем для комах і хвороботворних організмів [3]. Утилізації харчових відходів у світі приділяється досить багато уваги, розроблені та реалізовані багато напрямів їх повторного використання які потрібно довести до українського підприємця.

\section{Аналіз останніх}

досліджень. Досвіду європейських країн 3 використання та системи складування відходів присвячена робота Зигун А. Ю. У якій запропоноване вибіркове, або покрокове застосування заходів управління відходами, але, на жаль, не достатньо аргументована ця думка. Акцент аналізу автором ставиться на мінімізацію утворення відходів, а саме: зменшення кількості предметів і матеріалів, що скеровуються на остаточну утилізацію або поховання; відмова від зайвої упаковки; закупівлі тільки необхідної кількості предметів і матеріалів; використання предметів багаторазового або тривалого користування замість одноразових там, де це можливо [4]. За думкою Пікінера В. В. вирішення питання мінімізації утворення та повторного використання відходів у нашій країні можливе у разі оптимального поєднання адміністративних та екологоекономічних методів [5]. У дослідженні вартості життєвого циклу харчових відходів проведеного вченим Ф. Ді Менна вказано, що потрібно зосередитись на управлінні харчовими відходами, створенню умов, що сприяють зменшенню обсягів їх утворення [6]. Автори погоджуються із твердженнями зазначених вчених та пропонують детальніше зосередитись на механізмі зацікавленості підприємців до мінімізації обсягів утворення «їстівного, або гастрономічного сміття».

Метою дослідження $€$ визначення напрямів та економічне обгрунтування використання харчових відходів підприємствами готельно-ресторанного бізнесу.

Виклад основної частини дослідження. Фахівці стверджують, що скорочення харчових відходів на 20-50\% дозволить заощадити від 120 мільярдів доларів до 300 мільярдів доларів до 2030 року [2]. 3 ростом населення Землі проблема буде складнішою як стверджують екологи, тому важливим питанням постає завдання 3 мінімізації гастрономічних відходів.

На думку авторів, першим кроком до успішного пошуку шляхів створення механізму за яким підприємства виробники відходів будуть зацікавлені їх мінімізувати $\epsilon$ доведення знань про можливість отримання додаткового прибутку. У цьому за необхідним $\epsilon$ завдання розробки моделі утворення, складування та можливості використання гастрономічних відходів і шляхів отримання прибутку на рівні підприємства. Вона представлена на рис.1. Запропонована модель дає змогу чітко уявити види відходів, визначити можливість їх повторного використання чи утилізації у залежності від виду утворення, а також, що, на думку автора, $\epsilon$ дуже важливим, отримання додаткового прибутку. Саме через утворення 
механізму зацікавлення підприємстввиробників відходів та підприємств споживачів виникає можливість зменшення обсягів харчового сміття. Впровадження моделі, представленої нижче, для більшості підприємств $є$ перспективним направленням розвитку в майбутньому, адже вторинне використання харчових відходів - це не тільки додатковий прибуток, а й захист екології в цілому.

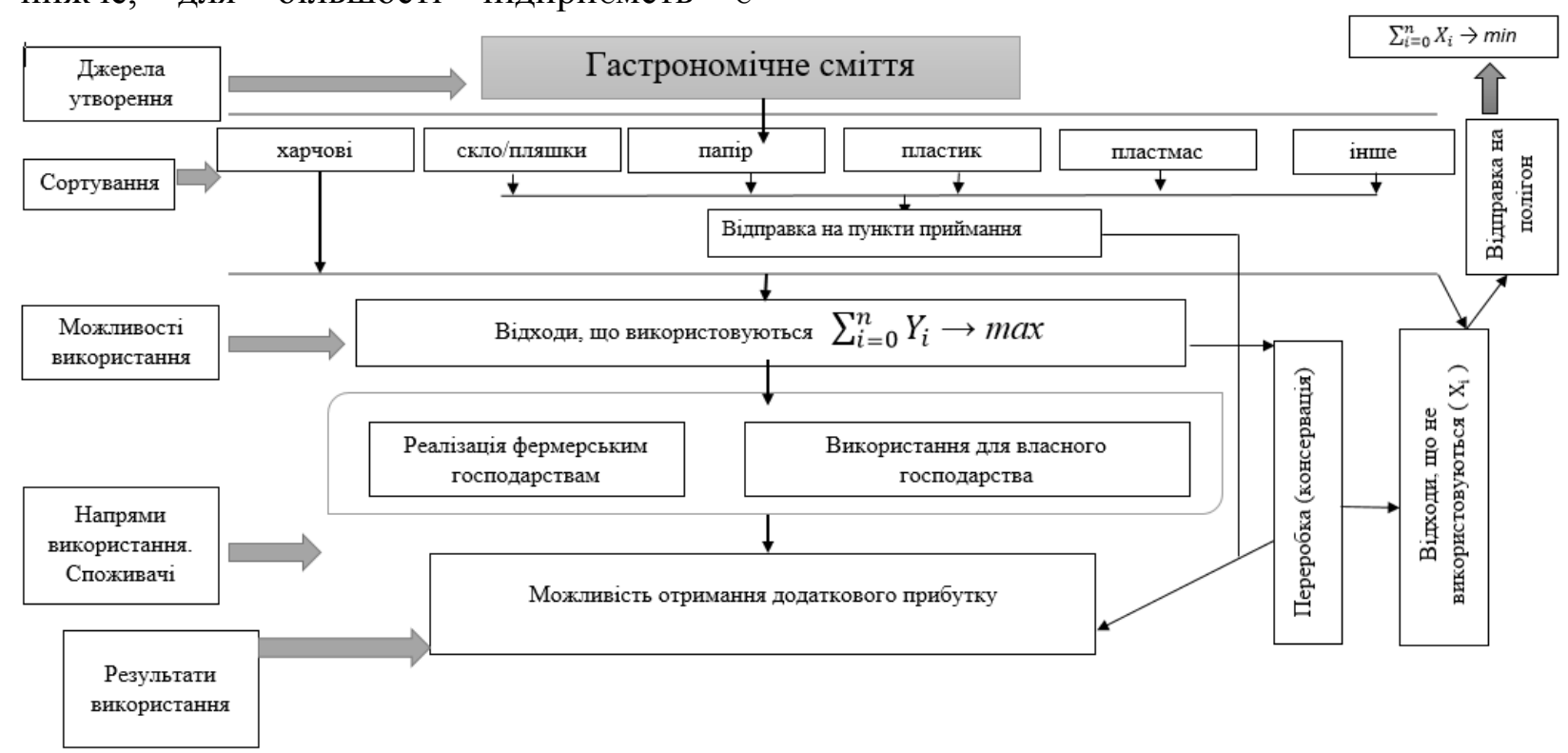

Рис. 1. Модель утворення, складування та можливості вторинного використання харчових відходів для підприємств [Авторська розробка за джерелом 7]

Наступним кроком, автори вважають за необхідне дослідити можливість практичної реалізації на підприємстві заходів із повторного використання відходів, їх сортування та переробки. Так, сортування відходів та реалізація на своєму власному фермерському господарстві були виконані на одному 3 підприємств готельноресторанного типу. Харчові відходи, що утворюються на цьому підприємстві умовно розділені на такі групи: рідкі відходи; м'які відходи (залишки приготованих м'ясних страв, мезга, шкірка, що утворюються в процесі чистки овочів тощо); тверді відходи (кістки, фруктові кісточки тощо); одноразова тара для упаковки продуктів. Через санітарні норми керівництво ресторану вимушено викидати багато продуктів, a саме, залишки їжі, які залишають відвідувачі, готові продукти, які не відповідають вимогам зберігання тощо. Також на підприємстві відстежується термін придатності продуктів та видаляються прострочені. Цей циклічний характер притаманний усім підприємствам такого типу. Усі зазначені відходи відправлялись на сміттєзвалище. На підприємстві 3 метою мінімізації усіх видів відходів пропонується до реалізації такі кроки:

1. сортування сміття (за розробленою моделлю класифікації відходів підприємств ресторанного бізнесу);

2. організація вивезення на пункти приймання (пункти приймання знаходяться у с. Дергачі);

3. вивезення на сміттєзвалище невикористаних харчових відходів;

4. організація збуту фермерам харчових відходів (не потребує навіть реклами, тому що кількість власників домогосподарств у селищі велика і усі зацікавлені в отриманні харчових відходів); 
5. організація утворення компосту (на території комплексу існує своя земельна ділянка де вирощуються овочі);

6. організація обслуговування мініферми (економічне обгрунтування цього напряму i його організація детально розглядається далі).

Зазначені заходи потребували відповідних змін у структурі персоналу, обов'язках персоналу, зміни у кошторисах, а саме:

- зміни у структурі підприємства (створення місця для сортування та складування відходів, зміна повноважень відповідальних посадових осіб);

- розробка кошторису витрат на утилізацію і сортування відходів;

- складання графіку реалізації проекту міні-ферми;

- розробка економічного обгрунтування запропонованих заходів.

Результати реалізації заходів 3 використання харчових відходів підприємством у разі створення мініферми зведені до табл.1.

Таблиияя 1

Економічне обтрунтування проекту організачії міні свиноферми

\begin{tabular}{|c|c|c|c|c|}
\hline \multirow{3}{*}{ Стаття } & \multicolumn{2}{|l|}{$1-и ̆$ рік } & \multicolumn{2}{|l|}{ 2-й рік } \\
\hline & Всього за рік & на голову & $\begin{array}{l}\text { Всього } \\
\text { рік }\end{array}$ & за \\
\hline & $\begin{array}{l}\text { Сума з ПДВ, } \\
\text { грн. }\end{array}$ & $\begin{array}{l}\text { Сума з П } \\
\text { грн. }\end{array}$ & $\begin{array}{l}\text { Сума } 3 \\
\text { грн. }\end{array}$ & $\begin{array}{l}\text { В, Сума з ПДВ, } \\
\text { грн. }\end{array}$ \\
\hline Доходи проекту & 338250 & 2255 & 338250 & 2255 \\
\hline виручка від реалізації & 338250 & 2255 & 338250 & 2255 \\
\hline дотації & - & - & - & - \\
\hline Витрати на вирощування & 246100 & 1640 & 246100 & 1640 \\
\hline Витрати на купівлю поросят & 132000 & 880 & 132000 & 880 \\
\hline Витрати на корми & 96600 & 644 & 96600 & 644 \\
\hline Витрати на ветпрепарати & 7100 & 47 & 7100 & 47 \\
\hline Вартість підстилки & 6300 & 42 & 6300 & 42 \\
\hline Вартість води & 4100 & 27 & 4100 & 27 \\
\hline Всього виплат за ангар & 70000 & 467 & 0 & 0 \\
\hline Всього витрат & 316100 & 2107 & 246100 & 1640 \\
\hline Заробіток мініферми & 22150 & 148 & 88760 & 592 \\
\hline
\end{tabular}

Дохід від створення міні-ферми збільшиться в 4 рази через рік, у разі успішного функціонування проекту протягом одного року.

У разі використання відходів харчування при утриманні одного поросяти протягом одного циклу за різними формами відгодовування витрати підприємства склали 1176,93 грн. Схема формування заробітку міні-ферми представлена у рисунку 2.

На підприємстві було виконане економічне обгрунтування заходів із сортування сміття. Витрати на вивезення гастрономічного сміття за 2017 рік та заплановані на 2018 рік подані у табл. 2-3.

Усього за рік витрати на вивезення сміття становлять - 18496 грн. При впровадженні системи сортування та скороченні харчових відходів, завдяки відкриття міні-ферми витрати на вивезення сміття становитимуть 7588 грн. Пляшки/пластик та папір/картон будете вивезений на продаж. Значення планового доходу наведено у табл.3. 


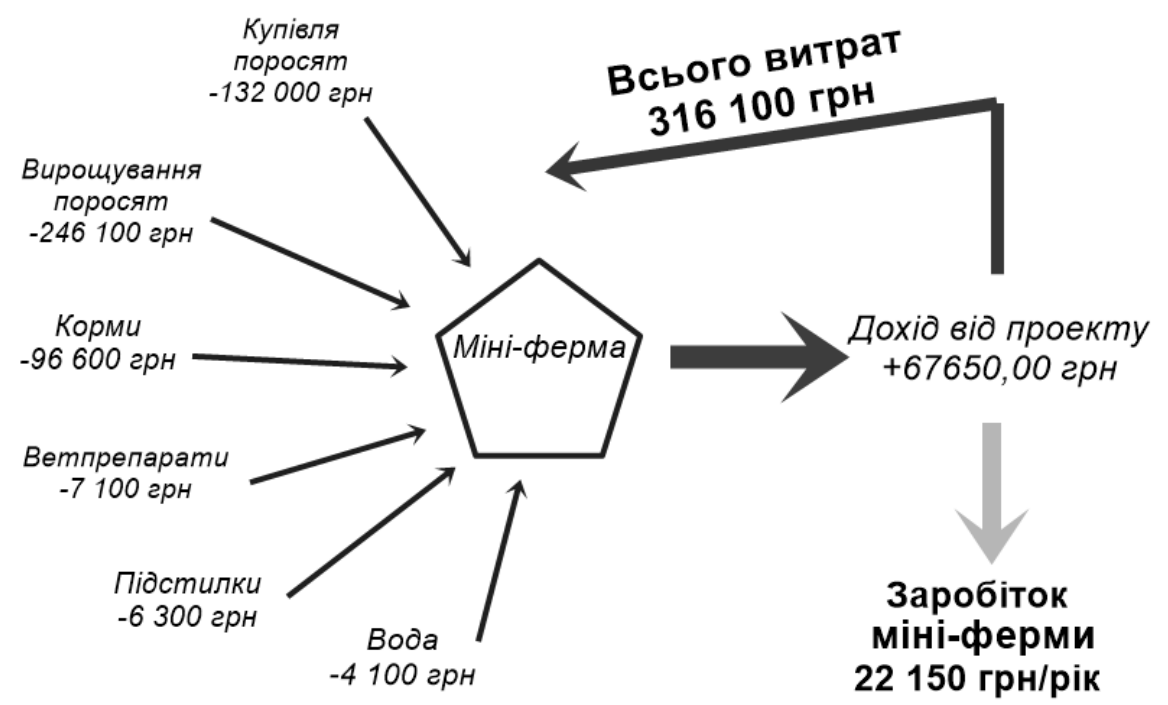

Рис.2. Схема формування заробітку міні-ферми [Авторська розробка за джерелом 30]

Таблиия 2

Витрати вивезення відсортованих відходів

\begin{tabular}{|c|c|c|c|c|c|c|c|c|c|c|c|c|}
\hline $\begin{array}{c}\text { Вид } \\
\text { сміття } \\
\text { (варті- } \\
\text { сть за } \\
\text { од. - } \\
350 \\
\text { грн/т) }\end{array}$ & 焉 & 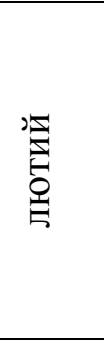 & 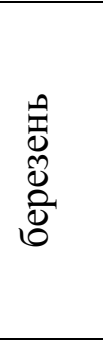 & 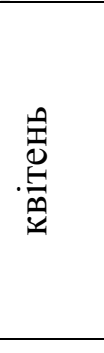 & 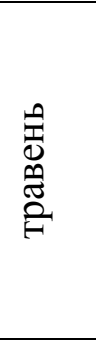 & 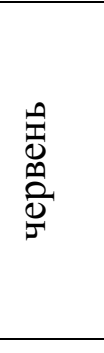 & 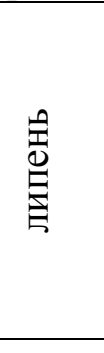 & $\begin{array}{l}\stackrel{\theta}{0} \\
\stackrel{0}{0} \\
己\end{array}$ & 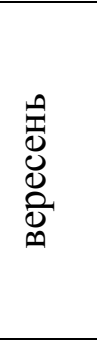 & 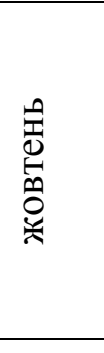 & 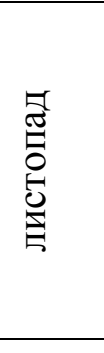 & 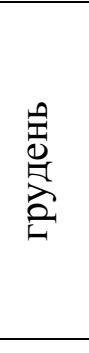 \\
\hline 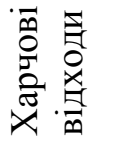 & 665 & 645 & 579 & 705 & 732 & 771 & 725 & 632 & 612 & 605 & 599 & 704 \\
\hline 苞 & 280 & 272 & 244 & 297 & 308 & 325 & 305 & 266 & 258 & 255 & 252 & 296 \\
\hline 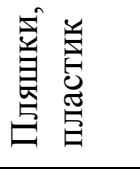 & 350 & 340 & 305 & 371 & 385 & 406 & 382 & 333 & 322 & 319 & 315 & 370 \\
\hline 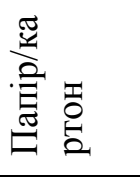 & 70 & 68 & 61 & 74 & 77 & 81 & 76 & 66 & 64 & 64 & 63 & 74 \\
\hline 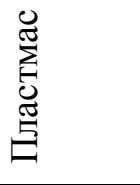 & 178 & 173 & 155 & 189 & 196 & 206 & 194 & 169 & 164 & 162 & 160 & 188 \\
\hline Усього & 1543 & 1497 & 1342 & 1635 & 1697 & 1790 & 1682 & 1466 & 1419 & 1404 & 1389 & 1632 \\
\hline
\end{tabular}

Вісник економіки транспорту і промисловості № 61, 2018 
Таблиия 3

Планові витрати вивезення відсортованих відходів

\begin{tabular}{|c|c|c|c|c|c|c|c|c|c|c|c|c|}
\hline $\begin{array}{c}\text { Вид } \\
\text { сміття }\end{array}$ & $\frac{0}{0}$ & $\begin{array}{l}\text { 昆 } \\
\text { 虽 }\end{array}$ & 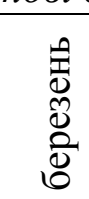 & $\stackrel{\theta}{. \oplus}$ & 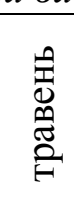 & 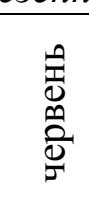 & 恚 & $\begin{array}{l}\text { 䓌 } \\
\text { 苞 }\end{array}$ & 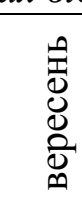 & 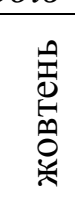 & 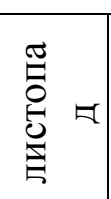 & 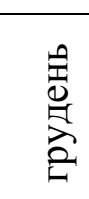 \\
\hline $\begin{array}{l}\text { Харчові } \\
\text { відходи }\end{array}$ & 175 & 170 & 152 & $\begin{array}{c}18 \\
6\end{array}$ & $\begin{array}{c}19 \\
3\end{array}$ & 203 & 191 & 166 & 161 & $\begin{array}{c}15 \\
9\end{array}$ & 158 & 185 \\
\hline Скло & 280 & 272 & 244 & $\begin{array}{c}29 \\
7\end{array}$ & $\begin{array}{c}30 \\
8\end{array}$ & 325 & 305 & 266 & 258 & $\begin{array}{c}25 \\
5\end{array}$ & 252 & 296 \\
\hline Пластмас & 178 & 173 & 155 & $\begin{array}{c}18 \\
9\end{array}$ & $\begin{array}{c}19 \\
6\end{array}$ & 206 & 194 & 169 & 164 & $\begin{array}{l}16 \\
2\end{array}$ & 160 & 188 \\
\hline Усього & 633 & 614 & 551 & $\begin{array}{c}67 \\
1 \\
\end{array}$ & $\begin{array}{c}69 \\
6 \\
\end{array}$ & 734 & 690 & 601 & 582 & $\begin{array}{c}57 \\
6\end{array}$ & 570 & 670 \\
\hline
\end{tabular}

У разі сортування відходів та визначеними пунктами приймання. Після вивезення на пункти прийому визначення найвигідніших за відстанню підприємством використовувалась місць приймання складений розрахунок інтерактивна карта м. Харкова 3 очікуваного доходу (табл.4).

Таблиияя 4

Плановий дохід від сортування відходів

\begin{tabular}{|c|c|c|c|c|c|c|c|c|c|c|c|c|c|}
\hline $\begin{array}{c}\text { Вид } \\
\text { сміття }\end{array}$ & $\begin{array}{c}\text { Варт } \\
\text { ість } \\
\text { за } \\
\text { од. }\end{array}$ & 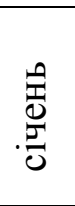 & 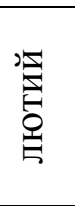 & $\begin{array}{l}\hat{D} \\
\mathbb{N}_{0} \\
\stackrel{D}{0} \\
0\end{array}$ & 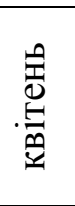 & $\begin{array}{l}\stackrel{0}{0} \\
0 \\
\stackrel{0}{0} \\
\stackrel{0}{0}\end{array}$ & 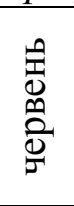 & 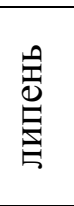 & 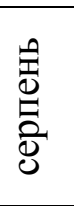 & 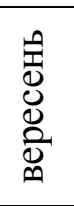 & 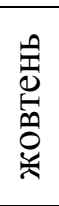 & 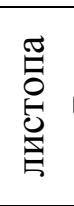 & 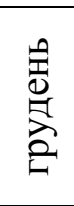 \\
\hline $\begin{array}{c}\text { Пляшки, } \\
\text { пластик }\end{array}$ & $\begin{array}{c}5500 \\
\Gamma р \mathrm{~s} / \\
\mathrm{T}\end{array}$ & $\begin{array}{c}110 \\
0\end{array}$ & $\begin{array}{c}106 \\
7\end{array}$ & $\begin{array}{c}95 \\
7\end{array}$ & $\begin{array}{c}116 \\
6\end{array}$ & $\begin{array}{c}121 \\
0\end{array}$ & $\begin{array}{c}127 \\
6\end{array}$ & $\begin{array}{c}119 \\
9\end{array}$ & $\begin{array}{c}104 \\
5\end{array}$ & $\begin{array}{c}101 \\
2\end{array}$ & $\begin{array}{l}10 \\
01\end{array}$ & $\begin{array}{c}99 \\
0\end{array}$ & $\begin{array}{c}116 \\
4\end{array}$ \\
\hline $\begin{array}{c}\text { Папір/кар } \\
\text { тон }\end{array}$ & $\begin{array}{c}2000 \\
\Gamma р \mathrm{~s} / \\
\mathrm{T}\end{array}$ & 80 & 78 & 70 & 85 & 88 & 93 & 87 & 76 & 74 & 73 & 72 & 85 \\
\hline
\end{tabular}

Усього за рік дохід становив 14146 грн. Сумарний ефект від організації збуту та використання гастрономічних відходів становитиме 36296 грн. за рік. Для досліджуваного підприємства визначена сума очікуваного сумарного доходу $\epsilon$ вагомою. Автори вважають, що сортування відходів та їх повторне використання є для багатьох підприємств вигідним i не складним для реалізації шляхом отримання додаткового прибутку.

Висновок. У роботі проведено дослідження стану накопичення відходів на сміттєзвалищах країни та представлена модель їх утворення, складування та встановлені можливості їх повторного використання для підприємств готельно ресторанного бізнесу, що дає змогу створити механізм зацікавлення підприємств - учасників такого ринку до мінімізації відходів. Це дало змогу запропонувати варіанти їх можливого використання на прикладі конкретного підприємства. У зв'язку з відповідністю розрахунків прибутковості підприємства 3 його реальною роботою протягом перших місяців, реалізація даного проекту $\epsilon$ доцільною та рекомендується до впровадження іншим підприємствам, які мають харчові відходи. Сучасні технології

Вісник економіки транспорту і промисловості № 61, 2018 
розширили спектр можливого використання різних відходів. Подальше дослідження варто провести у напрямах пошуку шляхів їх використання як вторинної сировини та розробці кроків їх практичної реалізації як на рівні підприємства так і на рівні країни.

\section{ПЕРЕЛІК ВИКОРИСТАНИХ ДЖЕРЕЛ}

1. Найбільш марнотратні країни або їстівне сміття [Електронний ресурс]. Режим https://harchi.info/articles/naybilshдоступу: marnotratni-krayiny-abo-yistivne-smittya Назва 3 титул. екрану.

2. Способы утилизации пищевых отходов [Електронний ресурс]. - Режим доступу: http://andeg-w.com.ua/sposobyutilizacii-pishhevyx-otxodov/ - Назва 3 титул. екрану.

3. Проблема отходов еды в ресторане [Електронний ресурс] // Режим доступу: http://www.restobaza.com/60othody-v-restorane - Назва з титул. екрану.

4. Зигун А. Ю. Використання світового досвіду системи управління відходами [Електронний ресурс] / А. Ю.Зигун // Lviv Polytechnic National University Institutional Repository - 2011. C.122-126. - Режим доступу: http://ena.lp.edu.ua

5. Пікінер В. В. Поняття “відходи”: правовий, економічний та обліковий підходи [Електронний ресурс] / В. В. Пікінер // Проблеми теорії та методології бухгалтерського обліку, контролю і аналізу. - 2012. - №3. - С.418-423. Режим доступу: http://pbo.ztu.edu.ua/article/view/42697/39355 6. F. De Menna, Jana Dietershagen, Marion Loubiere, Matteo Vittuary Life cycle costing of food waste: A review of methodological approaches [Електронний pecypc] / F. De Menna, Jana Dietershagen, Marion Loubiere, Matteo Vittuary // Waste Management, Volume 73, March 2018, p.113/ - Режим доступу: https://doi.org/10.1016/j.wasman.2017.12.032

7. Бутенко О. П. Ринок вторинних ресурсів та визначення його поняття / О. П. Бутенко, Т. Є. Андрєєва, А. В. Кучерук / Коммунальное хозяйство городов. - 2006. № 71. - С. 187-190

\title{
УДК 338.138
}

\section{ИССЛЕДОВАНИЕ ФАКТОРОВ, ВЛИЯЮЩИХ НА ПОВЕДЕНИЕ ПОТРЕБИТЕЛЕЙ В СОВРЕМЕННЫХ УСЛОВИЯХ}

\author{
Воловельская И.В., к.э.н., доцент, \\ Маслова В.А., к.э.н., доцент (УкрГУЖТ)
}

В современных условиях рыночные отномения отличаются все более жесткой конкуренцией между различными товаропроизводителями.

Выживание на рынке подразумевает сегодня работу не столько с товаром, сколько с потребителем. Это происходит из-за того, что во время всеобщей ориентации на потребителя физические свойства товара рассматриваются в большей степени с точки зрения психологического удовлетворения.

Взаимодействие с потребителем ведется в условиях инновационного развития технологий, постоянного увеличения ассортимента товаров, адаптирования имеющегося продукта под конкретного потребителя. Это напрямую указывает на

(С Воловельськая И.В., Маслова В.А.
Вісник економіки транспорту і промисловості № 61, 2018 